\title{
Burnout Syndrome and Drugs Use in the Family Health Strategy Nursing Team Brazilian
}

\author{
Adriane Batista de Araújo $^{1}$, Núbia Fernandes Teixeira ${ }^{2}$, Carla Denari Giuliani ${ }^{1}$ \\ Maria Cristina de Moura Ferreira ${ }^{1}$, Marcelle Aparecida de Barros Junqueira ${ }^{1}$ \\ ${ }^{1}$ Faculdade de Medicina \\ Universidade Federal de Uberlândia, UFU \\ Uberlândia - MG, Brasil \\ ${ }^{2}$ Instituto de Geografia \\ Universidade Federal de Uberlândia, UFU \\ Uberlândia - MG, Brasil
}

\begin{abstract}
Introduction: This research alludes to Burnout Syndrome within the team of nursing professionals (auxiliaries, technicians and nurses) of the Family Health Strategy (ESF). Objectives: To correlate the occurrence of Burnout Syndrome and drug use among nursing professionals in the Uberlândia Family Health Strategy. Describe the socio-demographic and work characteristics of nursing professionals. To identify the presence of Burnout Syndrome among nursing professionals. To characterize the profile of drug use among nursing professionals. Method: The research has a descriptive-analytical, quantitative character, performed according to CNS Resolution 466/12. Questionnaires were applied in a sample of 112 professionals in the UBSF's of the city of Uberlândia. Simple and applied statistics were used to collect the data. Results: The study showed that the sample was more predominantly female, from the age group of 30 to 49 years (adult phase) that are characteristics of the vulnerability to the disease. The sectors that includes the largest number of professionals are the South and West sectors. It was identified with the MBI - Maslach Burnout Inventory questionnaire that only $4.5 \%$ of the sample presented Burnout Syndrome, although it was found that $19.05 \%$ showed professional exhaustion and 7.9\%, depersonalization. These last data allude that a significant part of the professionals are more likely to develop the Syndrome. In fact, the relationship between drug use and job satisfaction was evaluated, which resulted in alcohol being the drug that had a greater predominance of use in relation to other drugs. With analysis of the statistics, it is perceived that this consumption rises to the level of the use of risk, which is very prone to develop dependency. Conclusion: The research alluded well to the problem. Situational leadership is a way for the health care team leader to decrease the propensity for Burnout Syndrome in their employees. After all, Burnout Syndrome makes it impossible for nurses to commit to nursing, because of its consequences reaching not only the professionals, but also the caregivers.
\end{abstract}

Keywords:- Burnout, professional. Nursing. Occupational health Introduction.

\section{INTRODUCTION}

The Family Health Strategy (ESF), previously called the Family Health Program (PSF) in Brazil, proposes a change in the health care model. An ESF objective is to reduce the distance between health teams and a population and to demand different skills from workers in this type of care. "The members of the ESF are in daily contact with the reality of communities, as in general, they are lacking in several aspects, which presupposes different resources and confrontations for workers" (Trindade and Lautert, 2010: 275).

Currently, in Brazil, an ESF is the product of a public policy aimed at changing this model of assistance. It proposes a team care practice - centered on the population's need, considering it as a participant in the process of producing health actions. Focused on the family, an FHS provides teams with an expanded understanding of the health / disease process and the need for prevention that goes beyond curative practices (Oliveira, et al., 2015).

According to Oliveira et al. (2015), since its implementation in 1994, the FHS has been seeking to guarantee equal access to health, taking as basic principles to integrality, hierarchy, territorialization, the multidisciplinary team and the substitutive character of the current model of health care.

This process of changes and adaptations can become a generator of conflict and, together with other factors, affect workers' health, as it is in the context of work that, sometimes, workers are in shock, due to the existing link between the commitment to profession and the system in which they are inserted (Lautert and Trindade, 2007).

ESF teams also face environments, most of the times, dangerous, unhealthy and conducive to health risk, which adds to the pressures and demands of the work itself, making this favor the development of Burnout Syndrome and other diseases related to work, such as the use of psychoactive substances (Benevides, et al., 2002).

The term Burnout refers to a syndrome of emotional exhaustion and cynicism that occurs frequently among individuals who work directly with people. The main aspect 
of Burnout Syndrome is the increase in feelings of emotional exhaustion, so that workers feel that their emotional resources are depleted and develop cynical and negative attitudes. Another aspect of the syndrome is the person's tendency to evaluate himself negatively, both in relation to his clients and to the workplace. This creates feelings of unhappiness and dissatisfaction among workers with their achievements at work (Maslach and Jackson, 1981; Maslach and Jackson, 1985).

In this sense, Costa et al. (2003), highlight that it is defined as one of the most striking consequences of professional stress. The Burnout Syndrome is characterized as a reaction to the chronic emotional tension generated from direct, excessive and stressful contact at work, which produces physical and psychological stress on the worker (Costa, et al., 2003).

Stress can occur in two ways, the first of an acute nature (very intense, but which disappears quickly) and the second of a chronic nature (not so intense, lasting for longer periods of time and the resources used by the individual to cope with it) scarce). Chronic stress contributes to a poor quality of life and an increased risk of several diseases, such as coronary heart disease, hypertension and low immune system (Calderero, Miasso and Corradi-webster, 2008).

The consequences of Burnout Syndrome at the organizational level and at work are represented by decreased quality of work, constant absences, decreased productivity, predisposition to work accidents, abandonment, absenteeism and turnover (Telles, 2008, Benevides-Pereira, 2010) .

The Burnout Syndrome was recognized in the early 1970s and was defined as "a condition of psychological distress related to work" (emphasis added), its origin is associated with physiological, behavioral and socioeconomic changes. Impaired immunity, hormonal and metabolic disorders, increased risk of cardiovascular events, chemical dependence on alcohol or other substances, suicidal ideas, anxiety, depression, decreased productivity at work and absenteeism are part of the broad spectrum of consequences of Burnout (Reinhold, 2004 ).

This syndrome is a psychosocial phenomenon that results from a chronic emotional tension, experienced by professionals whose work involves intense and frequent relationships with people who need some kind of care. It also needs to deal with the frustration of the inevitable failures and the feeling of helplessness when reality imposes itself in a constant start over again (Rios, 2008).

The use of the term Burnout is metaphorical. It refers to the person who has reached his limit and, due to lack of energy, has impaired physical and mental performance. There is no perfect translation, but the expression used by Helga Reinhold can be adopted: "to be consumed in flames". This same author defines Burnout as a gradual "erosion" of energy and disposition, initially imperceptible, which arises as a consequence of the chronic inability to control stress: "Burnout does not occur suddenly; it is a cumulative process, starting with small warning signs, which, when not noticed, can lead to a feeling of almost terror "(Reinhold, 2004).

Professional activities that guarantee survival and determine the individual's social situation, depending on the conditions in which the work is performed, can become painful and painful. For the worker, what could previously be something of motivation and satisfaction, becomes sacrificing, making the relationship difficult and with a possible drop in income (Chamon, et al., 2006).

The World Health Organization (2003) understands that the Burnout Syndrome is a risk for the worker and, judging to be a public health problem, in Brazil the Ministry of Health identified this syndrome as "professional burnout syndrome", a type of prolonged response to emotional and chronic interpersonal stressors present at work.

Professionals who establish direct contact with their public are more likely to feel incapable in the face of certain situations, such as dealing with problems that appear in the daily life of the workplace, tending not to recognize their success, generating personal unrealization, evidenced in the rationalization made explicit in the context of work and also in personal relationships (Gil-Monte, 2002).

National studies show that diseases due to mental and behavioral disorders are among the major causes of absenteeism and absence from work by nursing professionals. (Marques, 2013, Bernardes, et al, 2014, Manetti, Marzialle and Robazzi, 2008).

The nursing team, whose essence is permanent health care, is daily exposed to the risk of developing Burnout Syndrome. Often, this professional faces a large workload focused on direct contact with patients and family members, overload of responsibilities, double hours and coping and crisis management. In the nursing professional, this syndrome is harmful both in the individual and in the professional sphere, as it can negatively affect not only their health, but also the quality of care provided, thus interfering in the priority of the service, which is the technical and humanized ability in the service (Lorens, Benatti and Sabino, 2010).

Nursing work, especially with regard to organizational aspects, exposes workers to a series of physical and mental stressors, which can interfere with their ability to work and cause fatigue (Mauro, et al., 2010).

Faced with these workers' stressors, many use the use of drugs as an escape valve. Drugs are any and all substances, natural or synthetic, which, introduced into the body, modify their functions. Natural drugs are obtained through certain plants, animals and some minerals. Drug use is as old as humanity itself, and its consumption must be seen as a cultural and human manifestation (Barros and Pillon, 2007). 
According to Benevides-Pereira (2002), the degree, type and number of manifestations presented will depend on the configuration of individual factors (such as genetic predisposition, social, sociodemographic, educational experiences), environmental factors (workplaces or cities with a higher incidence of pollution, for example) and the stage in which the person is in the process of developing the Syndrome. The intensity, frequency, as well as the concomitance of stressors also influence, which may accelerate and / or aggravate the disorders and cause the use of drugs and psychoactive substances to start, in order to reduce the stressors of work.

Drugs are a generic name given to all types of natural substances or not, which, when introduced into the body, cause physical or psychic changes (Barros and Pillon, 2007). World Health Organization highlights that drug use is a problem that has been growing in terms of public health in developed and developing countries, reflecting on a range of problems involving the family and society with a strong economic impact (WHO, 2003 ).

Drugs are considered all substances that, when introduced, inhaled, injected or ingested in the organism, cause changes in its functioning, modifying one or more functions, causing it to modify the individual's state of balance. Although this definition is old, it becomes interesting, as it is directed to the psychic alteration caused by its use (Barros and Pillon, 2007).

Drug use is an ancient and universal human practice. In different societies, drugs were used for religious, cultural and medicinal purposes. Alcohol abuse is characterized by the link of intra and interpersonal relationships in society. This abuse is increasing alarmingly, in a study by the National Anti-Drug Secretary (SENAD). Currently, consumption occurs in an individualized and abusive manner, due to the huge amount of substances available on the market and ease of acquisition, elements that contribute to the dissemination and initiation of consumption (Marangoni and Oliveira, 2013).

Second, Raimundo et al. (2016), the consequences of harmful use of alcohol result in approximately 2.5 million deaths annually. Nowadays, research has been highlighting a certain type of intake, which is increasingly frequent and with important harmful consequences to health: binge drinking. It is a pattern characterized by the consumption of a large amount of alcohol in a short period of time, a practice described in the literature as binge drinking, or drinking in binge. This terminology is used to define "heavy episodic use of alcohol". It features a high-risk type of consumption and is often associated with a range of physical, social and mental problems. This pattern results in important neurophysiological changes (behavioral disinhibition, cognitive impairment, decreased attention, worsening judgment and decreased motor coordination).

According to Benevides-Pereira (2002) substance use is called use, which regardless of frequency or intensity (including sporadic or episodic use here), and abuse or harmful use is a consumption linked to recurring and significant adverse consequences, however, that does not meet the criteria for dependency. It is a pattern of psychoactive substance use that is causing harm to health. The damage may be physical (as in the case of hepatitis due to the administration of injecting drugs) or mental (eg, a depressive episode secondary to heavy alcohol consumption).

As the use of the drug becomes frequent, it is a determinant for addiction, it can be defined by a set of physiological, behavioral and cognitive phenomena, in which the use of a substance or a class of substances reaches a much higher priority for individual, than other behaviors that previously had more value. Dependence means that the act of using the drug has ceased to be a social function and an eventual pleasure and has become dysfunctional, an act in itself (Barros and Pillon, 2007).

The possibilities of this study are to make improvements, as it will interfere in the health of this public, making them able to have assistance and a better quality of life. The results of this study may enable a greater understanding of the problem in question and subsequently support an action plan for health professionals to be able to act directly and effectively, aiming at prevention.

In this way, the study can contribute to making changes within the professional scope, making it possible that, already knowing the reasons why these problems arise, we can intervene in a way that benefits not only our target audience, but also the study itself.

Thus, the study aimed to: Analyze the occurrence of Burnout Syndrome and the use of drugs by nursing professionals in the Family Health Strategy of Uberlândia, Brazil. Describe the socio-demographic and work characteristics of nursing professionals; Identify the presence of Burnout Syndrome among nursing professionals and Characterize the profile of drug use among nursing professionals.

\section{METODOLOGY}

This is a descriptive, cross-sectional study, with a quantitative approach, to identify the correlation between Burnout Syndrome and drug use among workers working in the ESF units, in Uberlândia (MG).The research took place in the city of Uberlândia (MG), where there are 74 ESFs, with work teams that vary in size.

The study was carried out with assistants, nursing technicians and nurses from the Family Health Strategy (ESF) teams in Uberlândia (MG). Currently, the ESF Nursing team consists of 73 nurses and 93 nursing technicians and assistants, in a total of 166 professionals. All professionals were invited to participate in the study. However, 112 subjects agreed to participate, thus making up the population of this study. 
Considering the ethical aspects related to research involving human beings (Resolution 196/96), the present study received authorization from the service for its realization, was submitted to the evaluation by the UFU Ethics and Research Committee, final substantiated opinion $\mathrm{n}^{\mathrm{o}} 1,315,972$ obtained in $10 / 11 / 2015$. All study participants were duly informed about the research, their rights and the care guaranteed to them. After agreeing to participate, they signed the Free and Informed Consent Term in two copies signed by the researcher and participant, one copy of the researcher and the other copy of the participant as regulated by the provisions of Resolution 196/96 of the National Health Council (Brazil, 1996).

Data collection was carried out between June and August 2016, where it was proposed to do with the FHS during this period. In this stage, meetings were held with nursing professionals so that everyone was notified. This meeting was between the Management of these locations that would first explain the purpose of the survey and, later scheduling to go to these locations for its application and scheduling with a minimum of seven and a maximum of 15 days to collect the questionnaires. After collecting all the information, we proceed to the second stage of our study, which is the launching in the database, that is, making the treatment of all the data collected during this research. This stage took place at the end of August until the beginning of September 2016.

One of the instruments for data collection was a structured, self-administered questionnaire, divided into: Sociodemographic and professional information. The questionnaire in which the sociodemographic variables were collected, included information regarding marital status, religion, race, occupational and educational situation with the intention of highlighting the characterization of the professionals. The second was the MBI (Maslach Burnout Inventory), developed in 1981 by Maslach and Jackson. MBI is one of the most used self-assessment instruments worldwide to measure Burnout Syndrome, its items were designed to measure hypotheses of aspects of the syndrome that characterize a worker with Burnout Syndrome. The items were written in the form of statements about personal feelings and attitudes (Maslach and Jackson, 1981). It was translated and adapted into Portuguese by Lautert (1995), with the current version of the MBI consisting of 22 fivepoint Likert-type items (statements), divided into three subscales: emotional exhaustion (9 items, $\alpha=0.88$ ), depersonalization (5 items, $\alpha=0.65$ ) and personal fulfillment ( 8 items, $\alpha=0.94$ ) (Telles, 2008).

The third instrument was the ASSIST (Alcohol, Smoking and Substance Involvement Screening Test), which is a structured questionnaire containing eight questions about the use of nine classes of psychoactive substances (tobacco, alcohol, marijuana, cocaine, stimulants, sedatives, inhalants, hallucinogens and opioids). It was developed by the World Health Organization (WHO) and an international group of researchers. ASSIST is aimed mainly at primary health care professionals for use in their work routines. The questions address the frequency of use, in life and in the last three months, problems related to use, concern about use by people close to the user, impairment in performing expected tasks, unsuccessful attempts to cease or reduce use, feeling of compulsion and injecting use (WHO, 2006).

And the fourth and last instrument used was the AUDIT (Alcohol Use Disorders Identification Test), which is a self-administered questionnaire, composed of sociodemographic data, family history (Babor, Fuente, Sauders and Grant, 1992). This instrument was developed by a group of researchers, under the auspices of the World Health Organization (WHO) and adapted for Brazil by Mendez (1999). AUDIT is an instrument that assesses problems associated with alcohol consumption and detects risky consumption patterns. It is particularly indicated for primary health care and used by different countries, in different cultural groups. The cut-off point for determining risky drinking consumption is 8 or more points. However, it can vary from study to study, and this pattern of risk consumption is associated with medical consequences, psychological and social problems, among others (Dawe, et al., 2002, Knibbe, et al., 2006, Croton, 2007 ).

For data analysis, a database was created using the Statistical Program of Social Science (SPSS) version 18 for Windows. The descriptive analysis of the data was presented in numbers, percentages, minimum and maximum values, means and standard deviation. The level of significance ( $p$ value) established was 0.05 for all variables.

In this program, the frequencies of each question were computed, to then perform the analyzes, based on the crossings between the variables. The 0.05 level of significance was established for the comparisons made with the Chi-Square test (Pereira, 1999).

The analysis of the MBI scale, considering scores greater than and equal to the 75th percentile in the Emotional Exhaustion and Depersonalization subscales, and the 25th percentile in the Personal Achievement subscale, according to the MBI validation study in Brazil (Lautert, 1995). Thus, dichotomous groups were created, that is, a group composed of participants who had scores compatible with Burnout Syndrome and another with participants who did not present the outcome.

Spearman's correlation coefficient was used in order to interpret and elucidate the relationship between drug use and the dimensions of Burnout Syndrome. This coefficient is a measure of association that requires the two variables to be measured at least at an ordinal level, so that one can order, that is, determine their rank. 


\section{RESULTS}

The sociodemographic characteristics show that the number of female professionals $(93.8 \%)$ is higher than that of men $(6.3 \%)$. Other characteristics noted were that $66.7 \%$ of the sample declared marital status as married, $55.7 \%$ completed higher education and we showed that most nursing professionals have a Christian religion (Catholic $46.3 \%$, evangelical $35.2 \%$, spiritist $14.8 \%$ ). We obtained the "unspecified" as a minority $(3.7 \%)$ that dealt with the alternative "others" of the question on religion in Appendix A.

In the age group distribution of the studied population, the age most frequently occurred between 30 and 49 years, with no difference between men and women. The analyzed professionals, $47(42.3 \%)$ were in the age group of 30 to 49 years old and $33(29.7 \%)$ of the professionals aged 50 years or older.
As for professional characterization, there are more nursing technicians (48.2\%) than nurses (47.3\%). Now, when the variable "position he holds" currently stands out, we notice that there is a greater number of nurses (40.4\%) than the number of nursing technicians $(48.6 \%)$. It is noteworthy that $11 \%$ of the sample are nursing assistants. We also find in Table 2, that $(31.5 \%)$ of the sample works in the South sector and per second, the Western sector $(23.1 \%)$.

Regarding drug use, it appears that alcohol in a binge pattern showed a higher percentage of use, with $44.6 \%$ of professionals making moderate use or risk. The use of alcohol (except binge) has $2.7 \%$ of risky or addictive use among professionals, and tobacco also has $2.7 \%$ of use at this level.

\begin{tabular}{|c|c|c|c|c|c|c|c|}
\hline Dimensions & $\mathbf{N}$ & $\%$ & P value & Midium & Median & Dp & Min-Max \\
\hline Emotional Exhaustion & & & 0,001 & 19,63 & 19,00 & 6,83 & $09-37$ \\
\hline Low & 21 & 18,8 & & & & & \\
\hline Moderate & 47 & 42,0 & & & & & \\
\hline High & 21 & 18,8 & & & & & \\
\hline Did not answer & 23 & 20,5 & & & & & \\
\hline Depersonalization & & & 0,014 & 7,91 & 8,00 & 2,67 & $05-15$ \\
\hline Low & 24 & 21,4 & & & & & \\
\hline Moderate & 45 & 40,2 & & & & & \\
\hline High & 26 & 23,2 & & & & & \\
\hline Did not answer & 17 & 15,2 & & & & & \\
\hline Professional achievement & & & 0,227 & 31,05 & 32,00 & 5,12 & $08-40$ \\
\hline Low & 23 & 20,5 & & & & & \\
\hline Moderate & 36 & 32,1 & & & & & \\
\hline High & 28 & 25,0 & & & & & \\
\hline Did not answer & 25 & 22,3 & & & & & \\
\hline Burnout & & & 0,000 & & & & \\
\hline Yes & 5 & 4,5 & & & & & \\
\hline No & 107 & 95,5 & & & & & \\
\hline
\end{tabular}

Table 1:- Burnout syndrome among ESF nursing professionals, Uberlândia, MG, Brazil 2016, (n = 112).

Table 1 illustrates the variable "professional achievement" had an average of 31.05 among ESF professionals in the city of Uberlândia. When referring to the variable "professional exhaustion", we have 19.63. And the lowest average in the present study found was the variable "depersonalization" 7,61. Burnout Syndrome was identified in 4.5\% of the professionals out of a total of 112 interviewed. 
ISSN No:-2456-2165

\begin{tabular}{|c|c|c|c|c|}
\hline & & Emotional Exhaustion & Depersonalization & $\begin{array}{l}\text { Professional } \\
\text { achievement }\end{array}$ \\
\hline \multirow{2}{*}{ Alcohol } & $\rho:$ & 0,018 & 0,167 & $-0,283$ \\
\hline & $\mathrm{p}$ value & 0,879 & 0,146 & 0,017 \\
\hline \multirow[t]{2}{*}{ Alcohol (Binge) } & $\rho:$ & $-0,003$ & $-0,220$ & $-0,240$ \\
\hline & $\mathrm{p}$ value & 0,983 & 0,100 & 0,862 \\
\hline \multirow[t]{2}{*}{ Tobacco } & $\rho:$ & 0,27 & $-0,17$ & 0,008 \\
\hline & $\mathrm{p}$ value & 0,819 & 0,888 & 0,951 \\
\hline \multirow[t]{2}{*}{ Marijuana } & $\rho:$ & 0,015 & $-0,035$ & $-0,141$ \\
\hline & $p$ value & 0,904 & 0,764 & 0,249 \\
\hline \multirow[t]{2}{*}{ Cocaine, crack } & $\rho:$ & 0,009 & $-0,039$ & $-0,141$ \\
\hline & $\mathrm{p}$ value & 0,941 & 0,743 & 0,249 \\
\hline \multirow[t]{2}{*}{ Amphetamine } & $\rho:$ & - & - & - \\
\hline & $\mathrm{p}$ value & - & - & - \\
\hline \multirow[t]{2}{*}{ Inhaling } & $\rho:$ & - & - & - \\
\hline & $\mathrm{p}$ value & - & & - \\
\hline \multirow[t]{2}{*}{ Sedative } & $\rho:$ & 0,197 & $-0,154$ & $-0,196$ \\
\hline & p value & 0,096 & 0,183 & 0,198 \\
\hline \multirow[t]{2}{*}{ Hallucinogenic } & $\rho:$ & - & - & - \\
\hline & $\mathrm{p}$ value & - & - & - \\
\hline \multirow[t]{2}{*}{ Opium } & $\rho:$ & - & - & - \\
\hline & $\mathrm{p}$ value & - & - & - \\
\hline Others & $\rho:$ & - & - & - \\
\hline Alcohol & $\mathrm{p}$ value & - & - & - \\
\hline
\end{tabular}

Table 2:- Correlation between Burnout Syndrome and drug use among ESF nursing professionals, Uberlândia, MG, Brazil, 2016 (n =112).

Table 2 showed a significant negative correlation between alcohol consumption and professional achievement, indicating (-0 283) that the lower the achievement professional, the greater the consumption of alcohol. And for the other drugs, there was no significant correlation.

\section{DISCUSSION}

Ezaias et al. (2010) consider the female gender as a vulnerable factor to Burnout Syndrome, which demonstrates an association between this field of work and women. When we show in Table 1 that women represent a greater proportion of the sample $(93.8 \%)$, being perhaps more vulnerable to the risk of manifesting the Syndrome, since the individual factors associated with it affect more female people due to their greater propensity for emotional exhaustion, while men tend to depersonalization. Remembering that emotional exhaustion is the main factor that propels the Syndrome.

Ezaias et al. (2010) also highlight that the most frequent manifestations of the dichotomous feeling "incompetence / lack of professional fulfillment" are observed in older individuals, who have already reached experience and familiarity with the situations related to their activities. Related to the age group of the sample, there was a greater proportion of age between 30 and 49 years, with no difference between men and women $(42.3 \%$ were in the age group of 30 to 49 years; $29.7 \%$ of professionals were 50 years old. or older). Thus, we perceive one more factor that deserves attention, since such audience has the characteristics highlighted by the authors.

Of the professional characteristics, Table 2 pointed out that in the South and West sector of the city of Uberlândia they had a greater number of professionals. This fact can be explained by the demand for work that the place needs. As illustrated by the Municipal Health Management Plan 20142017 (2013), the South sector has $21.03 \%$ of 604,013 inhabitants, that is, equivalent to 127 thousand inhabitants. While in the Western sector, it accounts for $23.49 \%$ of 604,013, which is equivalent to 142 thousand inhabitants. In comparison, in order to affirm such consideration, in the Central sector, which presented $1.9 \%$ of the sample of professionals, there is only $14.19 \%$ of 604,013 , which is equivalent to approximately 86 thousand inhabitants. 
According to Rolim (2013), the Burnout Syndrome is related to the variable that comprises the demand for work. In the case of the study, we consider that the greater the number of population, the greater the demand for services offered by the professional, resulting in emotional and physical wear and tear, being, therefore, a factor that deserves to be better observed in other studies.

Zeferino et al. (2006), in their review article, reflect that many health professionals use drugs in an attempt to reduce or reverse the signs of Burnout Syndrome. In the study by Rocha and David (2015) it also similarly addresses the idea already mentioned, that is, that the use of the psychoactive substance is a means that the nursing worker tries to minimize tension and stress. This mechanism used to deny or reduce the perception of suffering from reality, is often associated with inadequate working conditions, which is confirmed by the results found in this study: that $44.6 \%$ of professionals make moderate use or risk, the use of alcohol ( except binge) has a $2.7 \%$ use of risk or dependence among professionals, and tobacco also has a $2.7 \%$ use at this level. In the case of another study, Raimundo et al. (2016), consumption in binge reached a percentage of $80.7 \%$, when compared to our study, it is a high rate of consumption in this sense.

When comparing the results of this study on the Burnout Syndrome with another research, Pereira (2013) observed that the highest value of the average of the dimensions of the Syndrome occurred in the variable "professional achievement" with 30.5, demonstrating that most professionals they are satisfied with their work and are professionally done. Soon after, it was observed that the variable "professional exhaustion" with 24.3 The "depersonalization" variable had an average of 9.5, being the lowest of the variables in this regard.

In our study, we observed that the variable "professional achievement" was more significant, averaging 31.05 , that is, FHS professionals in the city of Uberlândia feel more professionally fulfilled. However, in the variable "professional exhaustion", the average was 19.63, and in the dimension "depersonalization", the average was 7.61, indicating worse feelings compared to the aforementioned study.

When using the MBI questionnaire (Maslach Burnout Inventory) about its usefulness in diagnosing Burnout Syndrome, in the current study, it was noticed that only $4.5 \%$ of the total sample showed signs of the Syndrome. According to Houtman (1998) a German survey estimated that $4.2 \%$ of its population of workers were affected by the Syndrome, where we can emphasize that the Syndrome compromises the care offered by these professionals, which puts the life of the population in insecurity. The results obtained allow some important considerations Benevides (2002).
When we came across in our research, the relationship between alcohol consumption and professional achievement was inversely proportional (negative correlation), we saw that the less the person expresses satisfaction about their work, the more chance to use some drug is apt. In that study, the result with alcohol was observed. According to Gabatz, Johann, Terra, Padoin, Silva and Brum (2013) professional dissatisfaction is a frustration that the person (nursing professional or not) can propose to the use of alcohol.

In this perspective, we consider the motivation of the work of these professionals to be extremely important, since they are in direct contact with the population. Motivation relates directly to factors that reside outside the individual exhaustion, personal, financial, love life, etc. The lack of it can cause exhaustion, dissatisfaction and other dimensions already mentioned in Burnout Syndrome.

According to the study by Mauro, Pinheiro, Paz, Silva and Mauro (2010) the worker's health reflects and interferes with their daily work and work influences their health in general. Between a person and his material, psychological and social work environment, there is a permanent interaction that can influence positively or negatively on that person's health, since the physical and mental well-being of the worker interferes with his productivity. We can observe that the short time devoted to rest are situations that also compromise the mental health of the nursing worker, which can cause personal problems, interpersonal relationships and the performance of their professional activities.

Therefore, those who supervise the services or administration, the sectors must know what the phenomenon of situational leadership consists of. Because through this leadership, according to Hersey and Blanchard (1997), the leader will recognize and evaluate the factors that interrelate between the amount of guidance and direction (task behavior), the amount of social and emotional support (relationship behavior) and the subordinates' level of readiness ("maturity") in the performance of a task, function or objective. This leadership enables nurses to mediate in the team's relationship with their work and seek to reduce the factors that stimulate the manifestation of signs of Burnout Syndrome - emotional exhaustion, physical exhaustion, dissatisfaction with work, etc.

Another measure to control the Burnout Syndrome, according to Tamayo, Tróccoli (2002), the alternatives for the prevention of the syndrome were less bureaucracy, limitation of the number of patients seen and a greater amount of continuing education.

According to Matubaro, Lunardelli, Ellaro, Bulhões and Souza (2007), professionals looking to have a hobby, who practiced regular physical activity, had more time and experience in the area of activity, who had a specialist title, among others, have no chance of develop Burnout Syndrome. 


\section{CONCLUSION}

It was identified that more than a third of the ESF professionals consume alcoholic beverages in an abusive or dependent manner, and the greater the consumption of these, the lower the professional achievement of the nursing worker.

The study showed that $4.5 \%$ of the sample had Burnout Syndrome, with $19.05 \%$ showing professional exhaustion and $7.9 \%$ depersonalization. These latest data suggest that a significant number of professionals are more likely to develop the syndrome.

It is noted that $44.6 \%$ use alcohol and the binge pattern and the negative correlation between Burnout and alcohol, because when we realize that these professionals are satisfied, professionally performed, the consumption of this type of drug decreases, that is, it is noticed that the use of this drug is to relieve tensions, stress, failure to accomplish what was proposed during the work period.

It is perceived that for professional success and good quality of care, it is necessary to rethink strategies that reduce frustrations at work.

With this, we can see that the Burnout syndrome in nursing workers is harmful in the individual, professional and organizational spheres, as it negatively affects the quality of nursing care to patients, family members and institutions at a time when humanization is necessary and of great importance in this environment.

The factors that contribute to low professional achievement are the precarious working conditions, such as inadequate physical structure and scarcity of material and human resources, the lack of investments that currently occur in relation to health programs. Thus, nursing workers are exposed to challenges and stresses at work that require skills to care for their patients.

Situational leadership can be a way that would solve this problem, since it is capable of causing changes in your environment. The health of the team of professionals depends not only on the commitment of its members and whether the objectives have been achieved, but mainly on their leader.

When thinking like future nurses, we understand that this leadership depends on the commitment, proactivity and autonomy of those who exercise team leadership. In this sense, we need to be aware of our health, as we need to have energy and wisdom to carry out such an exercise. With that, we are concerned with working with the motivation of the professionals.

After all, Burnout Syndrome does not only affect those who have it, but everyone with whom they relate, including the patient. And this makes the commitment to nursing impossible, which is to protect, guarantee and care for the health of those who need it.

\section{REFERENCES}

[1]. M. A. Barros, S. C. Pillon. "Atitudes dos profissionais do Programa Saúde da Família diante do uso e abuso de drogas". Esc. Anna Nery. v. 11, n. 4. Rio de Janeiro, 2007.

[2]. A. M. T. Benevides-Pereira, A. M. T. Burnout: quando o trabalho ameaça o bem estar do trabalhador. São Paulo: Casa do Psicólogo, 2002.

[3]. C. L. Bernardes et al. "Agravos à saúde dos trabalhadores de enfermagem em uma instituição pública de ensino". Rev Esc Enferm USP. v. 48, n. 4. São Paulo, 2014.K.

[4]. A. R. L. Calderero, A. I. Miasso, C. M. CorradiWebster. "Estresse e estratégias de enfrentamento em uma equipe de enfermagem de Pronto Atendimento". Rev. Eletr. Enf. [Internet]. n. 10, a. 1. Goiânia-GO, 2008.

[5]. E. M. Q. de O. Chamon, R. de C. Marinho, A. L. de Oliveira. "Estresse Ocupacional, Estratégias de Enfrentamento e Síndrome de Burnout: um estudo com a Equipe de Enfermagem de um Hospital Privado do Estado de São Paulo". In: $30^{\circ}$ Encontro da ANPAD (Associação Nacional de Pós- 48 Graduação e Pesquisa em Administração), Salvador, BA, 23 a 27 de setembro de 2006.

[6]. W. Codo. "Educação: carinho e trabalho. Petrópolis, RJ: Vozes/Brasília: Confederação Nacional dos Trabalhadores em Educação": Universidade de Brasília. Laboratório de Psicologia do Trabalho, 1999 in: DUNN, C. H. \& DUNN, G. D. Combatting stress in the OR. Today's OR Nurse, v. 8, n. 3, 1986.

[7]. G. M. Ezaias et al. "Síndrome de Burnout em trabalhadores de saúde em um hospital de média complexidade". Rev Enferm UERJ. n 18, a 4. Rio de Janeiro-RJ, 2010.

[8]. P. R. Gil-Monte, M. S. Carlotto, S. G. Câmara. "Validação da versão brasileira do 'Cuestionario para la evaluación del síndrome de quemarse por el trabajo"”. Rev Saúde Pública, v. 44, n. 1, São Paulo, 2010.

[9]. S. V. Gomes, J. P. Passos. "As doenças ocupacionais originadas frente à exposição de riscos ocupacionais na prática dos profissionais de enfermagem". R. pesq.: cuid. Fundam. Online. n. 2, Edição Suplemento., Rio de Janeiro, 2010

[10]. I. F. S. Henrique, D. Micheli, R. B. Lacerda. "Validação da versão brasileira do teste de triagem do envolvimento com álcool, cigarro e outras substâncias (ASSIST)". Revista Associação Médica Brasileira, v. 50, n. 2, São Paulo, 2004.

[11]. E. C. Lentine, T. K. Sonoda, D. T. Biazin. "Estresse de Profissionais de Saúde das Unidades Básicas do Município de Londrina". Terra e Cultura, n. 37, Londrina (PR), 2003.

[12]. S. R. Marangoni, M. L. F. de Oliveira. "Fatores desencadeantes do uso de drogas de abuso em mulheres". Texto Contexto Enfermagem, v. 22, Florianópolis, 2013. 
[13]. K. C. A. Matubaro et al. A síndrome de burnout em profissionais da saúde: uma revisão bibliografica. Faculdade de Ciências, Bauru (SP), 2007.

[14]. M. Y. C. Mauro et al. Condições de trabalho da enfermagem nas enfermarias de um hospital universitário. Ecs Anna Nery Rev Enferm, Rio de Janeiro-RJ, 2010.

[15]. C. Maslach, S. E. Jackson. "The measurement of experienced burnout". Journal of Occupational Behaviour, v. 2, n. 1, [s. 1.] 1981.

[16]. C. Maslach, S. E. Jackson. "The role of sex and family variables in burnout". Sex Roles, v. 12, n. 7, [s. 1.] 1985.

[17]. F. Meneghini, A. A. Paz, L. Lautert. Fatores ocupacionais associados aos componentes da síndrome de burnout em trabalhadores de enfermagem. Texto Contexto Enferm, v. 20, n. 2, Florianópolis-SC, 2011.

[18]. E. M. Oliveira et. al. "Determinantes sócio-históricos do cuidado na Estratégia Saúde da Família: a perspectiva de usuários da área rural". Saude soc. [online], v.24, n. 3,São Paulo, 2015.

[19]. M. F. R. A. Raimundo et al. "Consumo de álcool no padrão binge e suas consequências em usuários de drogas em tratamento". Rev. Eletr. Enf. [Internet], v. 18 Goiânia, 2016.

[20]. H. Reinhold. O sentido da vida: prevenção do stress e burnout em professores. (Tese de Doutorado). Campinas (SP), PUC, 2004.

[21]. P. R. da Rocha, H. M. S. L. David. "Padrão de consumo de álcool e outras drogas entre profissionais de saúde: retrato de alunos de cursos lato sensu de uma instituição pública”. SMAD, Rev. Eletrônica Saúde Mental Álcool Drog. Ribeirão Preto (SP), 2015 (Ed. port.).

[22]. S. S. Rossi, P. G. dos Santos, J. P. Passos. "A Síndrome de Burnout no enfermeiro: um estudo comparativo entre atenção básica e setores fechados hospitalares". Revista Pesquisa: Cuidado é Fundamental Online, v. 2, Rio de Janeiro, 2010.

[23]. A. de M. M. Rubiatti. Alcoolismo - estudo epidemiológico no município de Araraquara (SP). 2008. Tese (Doutorado) - Curso de Ciências Farmacêuticas, Universidade Estadual Paulista Júlio de Mesquita Filho, Araraquara (SP), 2008.

[24]. T. Spindola, E. R. da C. Martins. "O estresse e a enfermagem - a percepção das auxiliares de enfermagem de uma instituição pública”. Escola de Enfermagem Anna Nery, Rio de Janeiro, 11 jun. 2011.

[25]. L. L. Trindade, L. Lautert. "Síndrome de Burnout entre os trabalhadores da Estratégia de Saúde da Família”. Revista da Escola de Enfermagem da USP. v. 44, n. 2. São Paulo, 2010.

[26]. T. R. Trigo, C. T. Teng, J. E. C. Hallak. "Síndrome de burnout ou estafa profissional e os transtornos psiquiátricos". v. 34, n. 5, São Paulo, 2007.

[27]. M. R. Tamayo, B. T. Trócolli. "Exaustão emocional: relações com a percepção de suporte organizacional e com as estratégias de coping no trabalho". Estudos de Psicologia Exaust,,o emocional, UNB-DF, 2002.
[28]. G. Wehbe, C. M. Galvão. "Aplicação da Liderança Situacional em enfermagem de emergência”. Revista Brasileira de Enfermagem, v. 58, n. 1, São Paulo, fev. 2005. 